\title{
LONG-TERM FACTORS OF CONSTRUCTION BUSINESS DEVELOPMENT
}

\section{Bielienkova O. Yu.}

\section{INTRODUCTION}

Strategic management of construction business addresses vital areas like the strategy of operation, development and behavior of the industry under the influence of environmental changes, of promotion of construction work and development of human resources. At that, determination of the priorities in development substantially depends on the specific market situation in which the industry is functioning and on the state of the environment.

Therefore, it is extremely important to identify the conceptual foundations of development of construction business in Ukraine, the key fundamental trends that will affect its functioning over a long period, that is, those foundations that will have the greatest effect on the industry's ability to be competitive and control the strategic development on the basis of the forecasts for the future state of the environment. Without account of such trends, control is focused on the operational level only, at the best, on the tactical level as well. At absence of a strategy, this often fails to produce the desired result and leads to decrease of the rate of development of industry over the long run.

The main purpose of the study is to identify the most consequential trends in environmental changes (of economic, scientific and technical, socio-political environment, etc.) that in the coming years are to have an impact on the construction business functioning and should be taken into account when elaborating the strategy for further development.

For the construction activity, the main tendencies of development of the industry in strategic perspective are the further integration into the European Economic Area, after the entry into force in 2017 of the Association Agreement with the $\mathrm{EU}^{1}$, the implementation of the energy saving programs in all sectors of the economy and in the public sector, as a key element for the energy security of the State, ecological orientation of construction

${ }^{1}$ Decree of the Cabinet of Ministers of Ukraine of October 25, 2017 No. 1106 "On the Implementation of the Association Agreement between Ukraine, on the one part, and the European Union, the European Atomic Energy Community and their Member States, on the other part"« https://www.kmu.gov.ua/ua/npas/pro-vikonannya-ugodi-pro-asociaciyu-mizhukrayinoyu-z-odniyeyi-storoni-ta-yevropejskim-soyuzom-yevropejskim-spivtovaristvom-zatomnoyi-energiyi-i-yihnimi-derzhavami-chlenami-z-inshoyi-storoni 
projects, deregulation and liberalization of economy, the effect of the financial and economic crisis, digital transformation of the economy, etc.

\section{Pro-European vector of foreign economic and political development}

Ukraine's accession to the European Economic Area, implementation of joint international projects, harmonization of the systems of normalization and quality assessment of construction products, bringing the Ukrainian national standardization system in compliance with the requirements and rules according to which the national standardization systems of the European Union Member States operate.

The basis for the strategy of development of Ukraine for the coming years is the course for integration into the European Union and a step by step harmonization of Ukrainian legislation, norms and standards with the relevant EU documents..

So, in 2004 the Law of Ukraine "On State Program for Adaptation of the Legislation of Ukraine to the Legislation of the European Union" has been adopted $^{2}$, in 2010 - the Law of Ukraine "On Principles of Domestic and Foreign Policy"3, in 2014 - Resolution of the Verkhovna Rada of Ukraine "On confirmation of Ukraine's course towards integration into the European Union and priority measures in this direction" ${ }^{4}$, those have made it possible to take concrete steps towards European integration.

Besides that, among the legislative and regulatory acts in the field of European integration in the last decade one shall point out the Decree of the President of Ukraine "The Issues of European and Euro-Atlantic Integration", the Decrees of the Cabinet of Ministers of Ukraine "The Issues of preparation and holding of meetings of individual bilateral bodies of association between Ukraine and the EU", "The Issues of Publication of Decisions and Recommendations of the EU-Ukraine Association Council

${ }^{2}$ The Law of Ukraine "On the State Program for Adaptation of the Legislation of Ukraine to the Legislation of the European Union" No. 1629-IV of March 18, 2004 https://zakon2.rada.gov.ua/laws/show/1629-15

${ }^{3}$ The Law of Ukraine "On the Principles of Domestic and Foreign Policy" No. 2411-VI of July 1, 2010 https://zakon.rada.gov.ua/laws/show/2411-17

4 "On confirmation of Ukraine's course towards integration into the European Union and priority measures in this direction" No. 874-VII of March 13, 2014 https://zakon5.rada.gov.ua/laws/show/874-18

${ }^{5}$ The Decree of the President of Ukraine of April 20, 2019 No. 155/2019 "The Issues of European and Euro-Atlantic Integration" https://www.president.gov.ua/documents/155201926586

${ }^{6}$ The Decree of the Cabinet of Ministers of Ukraine of December 10, 2014 No. 700 "The Issues of Preparation and Holding of Meetings of Individual Bilateral Bodies of Association between Ukraine and the EU" https://zakon1.rada.gov.ua/laws/show/700-2014-\%D0\%BF 
and the EU-Ukraine Association Committee"7, "The Issues of planning, monitoring and evaluating the effectiveness of implementation of the Association Agreement between Ukraine, on the one part, and the European Union, the European Atomic Energy Community and their Member States, on the other part» ${ }^{8}$, "On the Government Office for Coordination of European and Euro-Atlantic Integration", "On introduction of a State mechanism for coordinating the interaction of public authorities in order to protect the financial interests of Ukraine and the European Union" ${ }^{10}$, the Decree of the Cabinet of Ministers of Ukraine of July 18, 2018 No. 577 "On the Coordination Council for Implementation of the Communication Strategy in the Area of European Integration for 2018-2021"11, as well as the Directive of the Cabinet of Ministers of Ukraine "On approval of the Communication Strategy in the field of European integration for 20182021 "12 "On approval of the action plan for 2018 on implementation of the Communication Strategy in the field of European integration for 20182021 "13 " On approval of the 2019 action plan for the implementation of the

${ }^{7}$ The Decree of the Cabinet of Ministers of Ukraine of March 04, 2015 No. 84 "The Issues of Publication of Decisions and Recommendations of the EU-Ukraine Association Council and the EU-Ukraine Association Committee" https://zakon0.rada.gov.ua/laws/show/84-2015$\% \mathrm{D} 0 \% \mathrm{BF}$

${ }^{8}$ The Decree of the Cabinet of Ministers of Ukraine of May 31, 2017 No. 447 "The Issues of Planning, Monitoring and Evaluation of the Effectiveness of Implementation of the Association Agreement between Ukraine, on the one part, and the European Union, the European Atomic Energy Community and their Member States, on the other part" https://zakon2.rada.gov.ua/laws/show/447-2017-\%D0\%BF

${ }^{9}$ The Decree of the Cabinet of Ministers of Ukraine of October 04, 2017 No. 759 "On the Government Office for Coordination of European and Euro-Atlantic Integration" https://zakon5.rada.gov.ua/laws/show/759-2017-\%D0\%BF

${ }^{10}$ The Decree of the Cabinet of Ministers of Ukraine of October 25, 2017 No. 1110 "On the introduction of a State mechanism for coordinating the interaction of public authorities in order to protect the financial interests of Ukraine and the European Union" https://www.kmu.gov.ua/ua/npas/pro-zaprovadzhennya-nacionalnogo-mehanizmu-koordinaciyivzayemodiyi-organiv-derzhavnoyi-vladi-z-metoyu-zahistu-finansovih-interesiv-ukrayini-tayevropejskogo-soyuzu

${ }^{11}$ The Decree of the Cabinet of Ministers of Ukraine of July 18, 2018 No. 577 "On the Coordination Council for Implementation of the Communication Strategy in the Area of European Integration for 2018-2021» https://www.kmu.gov.ua/ua/npas/pro-koordinacijnu-raduz-realizaciyi-strategiyi-komunikaciyi-u-sferi-yevropejskoyi-integraciyi-na-20182021-roki

${ }^{12}$ Directive of the Cabinet of Ministers of Ukraine of October 25, 2017 No. 779-r "On approval of the Communication Strategy in the field of European integration for 2018-2021» https://zakon2.rada.gov.ua/laws/show/779-2017-\%D1\%80

${ }^{13}$ Directive of the Cabinet of Ministers of Ukraine of April 25, 2018 No. 272-r "On approval of the action plan for 2018 on implementation of the Communication Strategy in the field of European integration for 2018-2021" https://zakon2.rada.gov.ua/laws/show/7792017-\%D1\%80 
Communication Strategy in the area of European Integration for 2018$2021^{\prime \prime 14}$.

In Ukraine, a number of significant steps have already been taken to adapt the domestic construction industry to European standards. So, in 2010 the Law of Ukraine "On Building Regulations" 15 has come into force, and from the 1 of July, 2014 - a mechanism for concurrent effect of the national building regulations and the building regulations harmonized with the EU regulatory documents. The provisions determining this mechanism of concurrent being in effect are set out in the Decree of the Cabinet of Ministers of Ukraine of May 23, 2011 No. 547 "Procedure for application of building regulations developed on the basis of the national technological traditions and building regulations harmonized with the normative documents of the European Union" and the DBN A1. 1-94: 2010 "Design of construction works according to Eurocodes. Basic provisions".

According to the aforementioned documents, the main direction for development of the regulatory framework in Ukraine is the implementation of national standards (norms developed on the basis of the national technological traditions) harmonized with the European Union normative framework at EUROCODE - the European unified building norms and regulations that have the status of European standards. The Eurocodes set common design criteria across the whole Europe, harmonize different national norms and regulations, and provide a single basis for a variety of scientific studies that facilitate the smooth exchange of products and services in the construction market.

According to the State Construction Standards (DBN) of Ukraine, DBN A.1.1-94: 2010. the Eurocode is a European standard for the design of building structures that contains the design requirements, and its main tasks are:

- to provide general criteria and design methods that meet the necessary requirements of mechanical resistance, stability and fire resistance at all types of loads, at that the requirements for the levels of safety (reliability) of buildings and constructions and the parts of those, with the aspects of durability and economy included, are a matter of the internal competence of the state;

14 Directive of the Cabinet of Ministers of Ukraine of January 30, 2019 No. 83-r "On approval of the 2019 action plan for the implementation of the Communication Strategy in the area of European Integration for 2018-2021" https://www.kmu.gov.ua/ua/npas/prozatverdzhennya-planu-zahodiv-na-2019-rik-z-realizaciyi-strategiyi-komunikaciyi-u-sferiyevropejskoyi-integraciyi-na-20182021-roki

${ }^{15}$ The Law of Ukraine “On Building Regulations” 1704-VI https://zakon.rada.gov.ua/laws/ show/1704-17 
- to serve as a basis at making contracts for design of buildings and constructions and the parts thereof, to facilitate the exchange of construction services (construction works and related engineering services), and to improve the functioning of the construction market;

- to provide a uniform understanding of the construction design process for the Ukrainian and foreign investors, customers, designers, contractors, etc.;

- to reduce the barriers and to facilitate the exchange of goods and services within the framework of construction activity of the participating States, to increase the competitiveness of the European construction firms, designers and manufacturers of structures and materials in the world market.

Introduction of European standards for the Ukrainian construction enterprises is of double importance. First, in the short and medium term, the companies will be forced to increase the expenses for the staff development and training, for tendering; besides that the effect of these documents males it possible for the European companies to enter the Ukrainian market on the basis of the rules being clear for them, to take part in tenders, this increases the level of competition in the industry. On the other hand, in the strategic perspective, training of personnel and removal of technical barriers for business activity (adaptation to European requirements) shall make it possible to develop the conditions for promotion of the domestic construction enterprises with entering international markets, and in addition to the European countries, from 2015, Kazakhstan and Belarus are going to to move to Eurocodes; and to gain additional competitive advantages at the domestic market as well.

Construction markets, according to the data of the Antimonopoly Committee of Ukraine, are attributed to the markets with a limited level of competition. However, the construction activity and production of building materials are for the year 2018 among the leaders in found out violations in the form of anticompetitive coordinated actions of economic entities by industries (69 in number) ${ }^{16}$. So, according to the share of products, works and services realized under conditions that exclude or substantially restrict competition was for the construction activity about $60 \%$. This is 1.57 times higher compared to the share of goods (works, services) realized under absolutely competitive conditions. In the construction sector (including the public works construction) in the markets having no structural restrictions on competition, only $25 \%$ of products, works and services were sold, while in the markets with oligopolistic structure $35.8 \%$, in markets with indications of domination of one economic entity and totally monopolized markets -

16 Report of the Antimonopoly Committee of Ukraine for the year 2018 http://www.amc.gov.ua/amku/doccatalog/document?id =148160\&schema=main 
$39.2 \%$. In this context, the EU-Ukraine Association Agreement will not only bring about the opportunities for finding new markets for construction companies, but it will increase as well the competition level in the domestic market.

\section{Implementation of the energy saving program as a priority direction for improving the economic security of the State}

Today, the main tendency in development of world energetics is the change of regional proportions of energy consumption, and the main task is to reverse the tendency of the outrunning growth of energy consumption by reducing the energy consumption of the economies. This is the most urgent task for developing countries with higher energy-intensive technologies compared to the developed countries.

There is an uneven increase of energy consumption in the world, with deepening regional energy imbalances: the highest rates are observed for the Asian countries, and especially for China, for which the energy consumption share has increased by $6 \%$ in recent years. Today, the number of countries and large regions with development not provided with their own energy resources is increasing. Beginning from the years 2005-2009, China, having surpassed the US, have captured the largest share of the world's energy consumption ( $12.45 \%$, compared to $11.39 \%$ of the US consumption); the share of energy consumption in Africa, Asia and the Middle East has grown, the share of the other region final energy consumption has decreased.

Despite numerous efforts, the structure of energy consumption in the world has not changed significantly over the last 25 years, and the dominant share of the most scanty resource - hydrocarbon fuel - continues to exist in the energy balance.

Today, the global economy is almost entirely dependent on the volumes of production of oil, natural gas, coal and other mineral fuels. The dependence of the developed countries on oil and natural gas imports is also projected to increase further. Oil will remain the main energy carrier in the coming decades, the share of natural gas will grow rapidly, and the share of coal will gradually decrease. It is likely that the maximum increment will be in solar, geothermal, wind and other alternative types of energy, though the cost of technologies and application of those is still very high. In electric power industry, the share of nuclear power plants is expected to decrease due to the fact that in the USA and Western Europe it is envisaged to replace the NPPs with the clean (gas) TPPs.

Many European and other developed countries are increasingly interested in alternative energy sources, and in some countries interest in nuclear energy is renewed. Though, along with that, hydrocarbon consumption 
globally has nowadays no serious alternative, this threatens scarcity of those with account of accelerated growth of energy consumption.

In 2019, the share of renewable energy sources in the world structure of energy consumption is still small compared to the traditional types of fuel and energy resources, with the largest share renewable energy in the EU countries (about $12 \%$ ). But at present there is a tendency of increase in the share of renewable energy sources in primary energy consumption of the European Union countries. Thus, the EU can take the leading position in the world in transition to the state-of-the-art energy technologies. This may be due to the fact that in the context of decrease in own traditional energy production and with constant increase in energy consumption, the EU countries are forced to import about $50 \%$ of the required energy resources.

Unlike most countries in the world where energy saving, though it is important, but is not more than one of the elements of economic and environmental policy, for Ukraine it is today a matter of survival. In market conditions and when entering the European and world markets, the energy component is a factor that substantially decreases the competitiveness of Ukrainian enterprises. At present, the main direction of reducing the energy intensity of products in all the sectors of economy is in formation of an effectively operating system of state management of the energy saving domain. The issues related to implementation of the energy-saving technologies and equipment in all the sectors of national economy (technological component) in the following areas are of great importance:

1. introduction of new energy saving technologies and equipment;

2. improvement of the existing technologies and equipment;

3. reduction of energy source losses;

4. improvement of product quality, improvement and reduction of losses of raw stock and materials;

5. replacement and selection of the most efficient energy sources.

According to the Energy Strategy of Ukraine for the period until 2035, developed in the context of the Sustainable Development Strategy "Ukraine 2020", approved by the Decree of the President of Ukraine, of January 12, 2015 No. $5^{17}$ providing, in particular, reformation of the power generation sector and implementation of the energy efficiency program within the stated pro-European vector of further development, the energy saving potential of the construction companies is not large (Table 1).

\footnotetext{
${ }^{17}$ Energy Strategy of Ukraine for the period until 2035 [Electronic source] - Access mode: https://zakon.rada.gov.ua/laws/show/605-2017-\%D1\%80
} 
Table 1

Energy saving potential of construction due to technical (technological)

factor (calculated by the author according to the data)

\begin{tabular}{|c|c|c|c|c|}
\hline Sector & 2010 & 2015 & 2020 & 2030 \\
\hline \multicolumn{5}{|c|}{ Fuel, million tons of reference fuel } \\
\hline Building and construction & 0.35 & 0.64 & 0.81 & 1,02 \\
\hline $\begin{array}{l}\text { Percentage of construction activity in } \\
\text { the total energy saving potential }\end{array}$ & $0.91 \%$ & $0.96 \%$ & $0.90 \%$ & $0.83 \%$ \\
\hline \multicolumn{5}{|c|}{ Electricity, billion $\mathrm{kWh}$} \\
\hline Building and construction & 0.04 & 0.1 & 0.1 & 0.18 \\
\hline $\begin{array}{l}\text { Percentage of construction activity in } \\
\text { the total energy saving potential }\end{array}$ & $0.23 \%$ & $0.26 \%$ & $0.26 \%$ & $0.25 \%$ \\
\hline \multicolumn{5}{|c|}{ Heat, million Gcal } \\
\hline Building and construction & 0.08 & 0.14 & 0.17 & 0.40 \\
\hline $\begin{array}{l}\text { Percentage of construction activity in } \\
\text { the total energy saving potential }\end{array}$ & $0.22 \%$ & $0.21 \%$ & $0.19 \%$ & $0.20 \%$ \\
\hline
\end{tabular}

Given that the construction industry provides reproduction of productive and nonproductive fixed assets, the role of construction enterprises in the state's energy sawing program can be considered as decisive. For the construction companies, this means that those have to refocus their activities on energy efficient materials, technologies, development of markets of energy saving construction in the residential and industrial sectors of the economy. The markets are at that divided into two types - reconstruction of existing buildings and designing new buildings with optimal energy consumption.

Another important step is the implementation of the European Union's experience in standardization of energy efficiency of buildings and constructions (the European Directive on the energy performance of buildings - Energy Performance of Building Directive, EPBD). This Directive is supported by more than $40 \mathrm{EN}$ standards, including those that characterize the total energy consumption of building, those standards determine the methods for calculation of energy consumption by individual engineering systems and the building as a whole, are determinative for the load on the heating and cooling of the building, state the rules for choosing the conditions of functioning of the buildings, with provision of monitoring and verification of marking and certification of energy efficiency of buildings.

Harmonization of national standards with account of the current base of construction regulations will create regulatory and methodological provisions for certification of energy efficiency of buildings and constructions in accordance with the Law of Ukraine "On Energy Saving". 


\section{Ecological focusing of construction}

Widespread in the EU countries are the directions of construction based on new environmental technologies, application of environmentally friendly materials and raw stock the use of which allows to reduce greenhouse gas emission to atmosphere, production of improved materials. Sustainable construction, along with improving the energy efficiency of buildings, is a part of the Global Green New Deal (GGND) direction, aimed at fostering the recovery of financial system, overcoming the recession in the economy, shifting the after-crisis development towards ecologically friendly and sustainable development, at job gains, according to the United Nations Environment Program (UNEP). To this end, a package of public investments, fiscal stimulus, pricing reforms is proposed to shift towards ecologically-oriented "green" economy, to create the appropriate infrastructure and increase employment in the transformed sectors of the economy. Compared to the traditional construction, the use of the "green standards" is more expensive, though this is a promising way to increase the competitiveness of construction companies and to reduce the negative effect of their activities on the environment.

Green Building Certification is a process of evaluating the design documentation of a building on compliance with the criteria of the green building standard, based on a scoring system of evaluation carried out by an authorized executive authority with issuing for the building contract specifier, the owner of the building having obtained the appropriate number of points, a certificate of green building.

The Green Building Certificate is the document that confirms the certification. The certification is voluntary, its criteria determine the compliance of the building with green building standards, namely:

- ecological criterion that includes calculated, with account of lessons learned from international methods, volumes of man-caused greenhouse gas emission, characteristics of influence on the ozone layer, indicators of internal microclimatic parameters of the building, indicators of quality and efficiency of drinking water use in the water supply system and conditions of water drain, outer surface use, characteristics of waste generation, sorting and utilization;

- economic criterion, including the amount of costs associated with the operation of the building, energy efficiency indicators of office building;

- a functional criterion that includes the thermal performance characteristics for the building in winter and summer seasons, acoustic characteristics, characteristics of natural and artificial lighting, ventilation, air conditioning, characteristics of temperature and solar exposure, accessibility for the users, characteristics of changeability; 
- a technical criterion that includes the fire safety indicator, indicator of noise exposure, humidity level in premises, an indicator of the convenience of cleaning and maintenance of the building, indicators of the solid waste content at demolition or dismantling of the building;

- location criterion that includes a measure of the degree of risks associated with the location, characteristics of traffic connectivity, of infrastructure development, location conditions.

There are many standards in the world that evaluate the energy performance of buildings - LEED, BREEAM, CASBEE, GREEN STAR and others. It is possible to apply different certification systems to new buildings and to existing ones as well, there are distinguished between the nominal and functional, mandatory (the European Union Energy Performance of Buildings Directive) and voluntary systems (BREEAM, LEED). There are more than ten standards highlighted for the voluntary certification systems in the world. Most of those are national in nature (Japan - CASBEE, Australia - GREEN STAR, NABERS, France - HQE, Germany - DGNB, etc.). The BREEAM (UK) and LEED (US), as well as DGNB's GSBC, are actively present at international market.

The international standards have stood out from a number of national standards through healthy market competition and are represented by two leading schemes - LEED and BREEAM. The choice usually depends on the country of construction or on the project owner's expectations. So, the US investors mostly get the LEED certificate and the European investors - the BREEAM one.

\section{Deregulation in construction activity}

Today, the construction sector in Ukraine undergoes substantial transformation at the organizational, legal and scientific and technical levels, one of the directions of those transformations is deregulation in construction activity. Regulation of construction activity by the state control and supervision instruments alone does not provide or to full extent the quality of products, the responsibility to respect consumer rights, and does not guarantee the absence of unfair market participants. Among specific examples of such deregulation and decentralization initiatives are the Law of Ukraine "On Regulation of Urban Development", the Law "On Amendments to Some Legislative Acts of Ukraine on Simplifying Business Conditions (Deregulation)" aimed at simplification of the procedures in construction industry. Those legislative proposals amend a large number of procedures in the construction sector in order to simplify the procedure, with obtaining documents for commencement of construction works and commissioning of facilities included, with the terms of issuance of technical specifications, submission of declaration on implementation of preparatory 
and construction works, the system of State supervision over decisionmaking in the area of urban development planning and implementation of architectural and constructional control, the mechanism of contestation of such decisions by the project owner. The concept of simplification of business operations involves removal of licenses, permits, regulations, certificates, prescriptions, with reduction of the periodicity of inspections and winding up respective units and national regulatory authorities. In addition, it is proposed to redistribute the functions for provision and control of implementation among different local authorities.

\section{Systematic effect of the financial and economic crisis, hostilities at the east of the State on the economy}

The crisis phenomena, having led to a decrease in production and a decrease in household income, have made a very negative impact on the economic state of the construction industry. Moreover, construction has turned out to be one of the most vulnerable sectors of economy at crisis. The slowdown in construction in Ukraine has began from the beginning of 2008, and by the end of the year it has become an abrupt decrease; and even in 10 consecutive years construction still has not reached the level of the year 2008.

The main negative factors that have determined the indicators in the construction sector are:

1. decrease in demand for construction products from both, population (housing development) and the public and private sectors (construction of objects for industrial, commercial, social purposes);

2. crisis in the financial sector of the country, lack of financial resources. During the last years before the crisis, high dependence of construction companies on the financial market was observed. Most of those companies worked on the basis of the borrowed resources of population, of institutional investors, banks, and thus deterioration of the conditions of access to borrowed funds became a significant disadvantage for these enterprises;

3. residential real estate price crash resulted in unprofitability of a large number of projects, the government programs aimed at supporting the construction of unfinished objects, of social and affordable housing are moving slowly, often with lack of funding for those;

4. reduction of paying capacity of partner companies, due to the shortage of liquidity the process of settlements is complicated;

5. the increase in prime cost caused by growth in the cost of energy sources and the drop in the hryvnia exchange rate has led to decrease in profitability of the main activity; 
6. temporary shutdown of investment activity by domestic enterprises under conditions of political and economic uncertainty, even the companies being able to invest, into construction as well, have slowed down their investments.

\section{Digital transformation of economy}

Digitization of all the spheres of activity of the State - from getting services and up to controlling the work volumes by means of cameras for supervision and drones, carrying out the big data analysis based on the basis of the Big-Data technology, storing information in «cloud» storage services, etc. Currently, the participants of the investment and construction process can monitor the progress of construction on-line ${ }^{18}$, without leaving the office, can make changes and updates to project in real-time mode, those immediately become open to other participants (BIM modeling) ${ }^{19}$, can control the quality and the volume of construction work by means of drones $^{20}$. The impact of the State on the economy of the country is to take place through harmonizing the policy of digitization with scientific and technical, budgetary, monetary and credit, industrial and foreign economic policies, provided that integration of interests and coordinated relationship between the society, the State, government, business, community and scientific institutions is achieved. It should by taken into account that the digital economy provides unprecedented opportunities for businesses and organizations to freely choose partners and consumers, facilitates market entry and promotion, substantially reduces transaction costs, facilitates decentralization, etc. Therefore, the digitization process will take place even in the case of State non-involvement or resistance, since it is a sign of continuous development of the economic system and means of ts transition to a new, qualitatively different level. In order for the digital transformation of the economic system to be managed, it is necessary to combine the efforts of scientific schools, of the participants of the investment-construction process, citizens, the State to achieve a balance of interests of all those groups at implementation of measures for digitization of economy.

The effective strategy for development of digital economy and construction sector is to be based on the productive potential of education and science, on the

${ }^{18}$ Zeltser R.Ya., Bielienkova O.Yu., Novak E., Dubinin D.V. Digital transformation of processes of resource-logistical and organizational-structural support of construction. Science and innovation. 2019, No. 15(5), P. 38-51.

${ }_{19}$ Nikolaiev V. P. Information modeling of buildings: imperatives of optimization of construction and operation process / V. P. Nikolaiev, T. V. Nikolaieva // Construction operations. - 2015. - No. 59. - P. 17-26.

${ }^{20}$ Zeltser R.Ya, Kolot M.A, Panasiuk I.O. The practice of using drones at implementation of construction projects in Ukraine. The ways to increase the efficiency of construction operations under the conditions of formation of market relations. 2018. No. 35. P. 151-154. 
development of new research studies, elaboration of new organizational solutions and connections, technologies, business processes, etc.

\section{CONCLUSIONS}

Consideration of the above factors will make it possible for the construction enterprises to elaborate their own development strategies more soundly, to identify the risk factors and evaluate their own capabilities. In view of the tendency of the crisis to continue, it is now important for construction companies to abandon the strategy aimed at increasing the volume of work and to focus on preparation for the economic recovery of the country. The key tasks at that are to be in retaining the market share, work on creating the image of a reliable partner, maintenance of own economic stability and strength.

\section{SUMMARY}

Ukraine's strive for integration to the European economic system has necessitated the restructuring and reorientation of the construction industry in order to increase the competitiveness of domestic enterprises on the principles of sustainable development and integration into the world economy.

This has necessitated the improvement of the regulatory framework, legal and technical regulation, standardization, certification, conformity assessment, the State supervision and control aimed at protecting the interests of the country, including the improvement of competitiveness of construction industry enterprises in order to ensure high quality, security of real estate objects and export orientation of enterprises.

Implementation of energy efficient technologies and economical consumption of energy resources, energy carriers from renewable energy sources and alternative fuels, adaptation of low-waste and non-waste technologies, use of secondary resources, use of facilities for production of non-traditional and renewable energy sources are objectively required for Ukrainian economy, along with meeting the requirements of ecological standards.

One of the trends in development of construction is decentralization and deregulation of construction, this is aimed at simplifying the business operations of individual companies and transferring powers of authority to local governments.

Analysis of the current state of digital transformation of construction activity shows that digitization is a rapid, irreversible, constant process of development of economic systems in the world. In Ukraine, the process of digitization has already begun at the level of individual economic operators and the level of regions, cities, states as well. In construction industry, the 
process of digital transformation progresses due to introduction of new information technologies, the Internet of Things, drones and more. This process requires support and regulation by the State. Interventions proposed for improvement of the mechanism of digital transformation of construction industry will help to manage the process of digitization on a controlled basis.

Further liberalization of the economy and reduction of doing business barriers, digitization of activity of construction companies are positive trends, while continued effect of socio-economic and financial crises, of armed hostilities at the east of the country are destructive factors. With account of those factors it is possible to build a construction sector development strategy that takes into account the key factors and is as close to real trends as possible. An effective strategy of the construction industry development should be based on the productive potential of education and science, development of new scientific studies, with generation of new organizational structures, interconnections, technologies, business processes, and more.

\section{REFERENCES}

1. The Law of Ukraine "On Regulation of Urban Development" with amendments and supplements [Electronic source] / Legislation of Ukraine. Verkhovna Rada of Ukraine. - Access mode: http://zakon4.rada.gov.ua/ laws/show/3038-17

2. The Law of Ukraine "On Building Regulations» [Text] / Bulletin of the Verkhovna Rada of Ukraine (BVR), 2010. No. 5, P. 41.

3. The Law of Ukraine "On Energy Saving" [Electronic source] / Legislation of Ukraine. Verkhovna Rada of Ukraine. Official Website Access mode http://zakon2.rada.gov.ua/laws/show/74/94-\%D0\%B2\% D1\%80

4. The Law "On Amendments to Some Legislative Acts of Ukraine on Decentralization of Powers in the Field of Architectural and Constructional Control and Improvement of Urban Development Legislation" [Electronic source] - Access mode http://search.ligazakon.ua/l_doc2.nsf/ link1/NT0925.html

5. The Law "On Amendments to Some Legislative Acts of Ukraine on Simplifying Business Conditions (Deregulation)" [Electronic source] Access mode http://w1.c1.rada.gov.ua/pls/zweb2/webproc4_1? pf3511=53076

6. Decree of the Cabinet of Ministers of Ukraine of 23.05.2011 No. 547 "Procedure for application of building regulations developed on the basis of the national technological traditions and building regulations harmonized with the normative documents of the European Union"

7. DBN A1. 1-94: 2010 "Design of construction works according to Eurocodes. Basic provisions"./Minregionbud. - K.: 2012 - 22 p. 
8. Report of the Antimonopoly Committee of Ukraine for 2013 [Electronic source] - Access mode http://www.amc.gov.ua/amku $/$ doccatalog $/$ document?id=103172\&schema=main

9. European Directive on the energy performance of buildings EPBD2010 (Energy Performance of Building Directive) [Electronic source] Access mode: http://www.bre.co.uk/filelibrary/Scotland/Energy_ Performance_of_Buildings_Directive_\%28EPBD\%29.pdf

10. Energy strategy of Ukraine for the period until 2030 [Electronic source] - Access mode: https://zakon.rada.gov.ua/laws/show/n0002120-13

11. Global Green New Deal. UNEP report. March 2009. [Electronic source] - Access mode: www.unep.org/greeneconomy

12. Bielienkova O.Yu. The impact of economic crisis on the financial state of enterprises of the type of activity "construction" / Bielienkova O.Yu. // Construction production. 2010. - Issue 52. - P. 16-20.

13. Bielienkova O.Yu. Economic Evaluation of Energy Efficiency Improvement Measures / Bielienkova O.Yu., Ostapenko I.O. // Construction production. Interagency Scientific and Technical Collection - 2013. Issue 55. - P. 28-31.

14. Goiko A.F. Efficiency of investment of reconstruction and technical re-equipment of existing enterprises / Goiko A.F. // Ways to increase the efficiency of construction under conditions of formation of market relations: Coll. Sci. Proceedings - K .: KSTUCA, 2009. - P. 64-74.

15. Sorokina L.V. Study of impact of macroeconomic regulators on the dynamics of capital accumulation in the construction sector of Ukraine / L.V. Sorokina // Actual problems of economy. - 2012. - No. 6. - P. 69-81. Access mode: http://nbuv.gov.ua/UJRN/ape_2012_6_10

16. An econometric toolkit for managing financial security of a construction company: [monogr.] / L. V. Sorokina, S. P. Stetsenko, A. F. Goiko, K. V. Izmailova, T. Yu. Tsyfra [et al.]; under sci. ed. of Doctor of Economics, prof. L. V. Sorokina. - K. : Kyiv National University of Construction and Architecture; Kryvyi Rih: Published SEP Cherniavskyi D. O., 2017. - P. 4-26.

17. Ryzhakova G. Implementation of principles of biospheric compatibility in the practice of ecological construction in Ukraine [Текст] / D. Chernyshev, I. Ivakhnenko, G.Ryzhakova, K.Predun // International Journal of Engineering \& Technology - UAE: Science Publishing Corporation, 2018- Vol 10. No 3.2: Special Issue 2 - pp. 584-586.

18. Tetyana Marchuk, Dmytro Ryzhakov, Galyna Ryzhakova and Sergiy Stetsenko (2017). Identification of the basic elements of the innovationanalytical platform for energy efficiency in project financing. Investment Management and Financial Innovations Vol. 14(4), pp. 12-20.

19. Maksymov A. S, Dovganiuk V.M, Vakhovych I.V, Tsyfra T.Yu. Theoretical and economic rationale for the measures to improve the energy 
efficiency of non-industrial objects. // - "Green" Economy - Movement Towards Sustainable Development: Collection of Materials - K.: ScientificResearch Economic Institute of the Ministry of Economic Development and Trade of Ukraine, 2013. - P. 113-116.

20. Energy Efficiency in the Municipal Sector. A manual for officials of local self-government / Maksimov A.S., Vakhoviych I.V., Gutnichenko T.P., Babicheva P.Ya., Vakulenko N.M., Tsyfra T.Yu. Et al. - Association of Ukrainian Cities under the USAID DIALOGUE Project, 2015. -184 p.

21. Belenkova O.Yu. Tendencies of construction industry development as factors of formation of strategic competitiveness of construction enterprises. // Construction production. Interagency Scientific and Technical Collection - 2014. - Issue 57. - P. 24-30.

22. Chupryna Yu. Informational and analytical supply of project simplemented byregional construction class // Innovative Solutions In Modern Science, № 6(25), 2018.

23. Goiko A.F. An Empirical Assessment of the Security of Economic Development of Construction Enterprises: A European Aspect / A.F. Goiko, L.V. Sorokina, V.A. Skakun // Coll. Sci. Proceedings "Ways to increase the efficiency of construction under conditions of formation of market relations" - Issue 40. Economic - K.: KNUCA, 2019. - P. 17-18.

24. Tsyfra T.Yu. Certification Systems - new realities of Ukraine / Tsyfra T.Yu., Derkach E.V. // Energy efficiency in construction and architecture - Scientific and Technical Collection. - Issue 8. K. : KNUCA, 2016. - P. 403-409.

25. Izmailova K.V. Ecological support of reserves as a factor of efficiency of use of fixed assets of construction company / K.V. Izmailova // Ways to increase the efficiency of construction : Coll. Sci. Proceedings issue 36. - 2018. - P. 3-7.

26. Tsyfra T. Yu. Practical experience of implementation of international construction contracts in Ukraine [Text] / T. Yu. Tsyfra // Construction production. - K., 2017. - Issue No. 63/2. - P. 78-85.

\section{Information about the author: Bielienkova O. Yu.,}

$\mathrm{PhD}$ in Economics, Associate Professor, Associate Professor at the Department of Construction Economics, Kyiv National University of Construction and Architecture 31, Povitroflotsky ave., Kyiv, 03037, Ukraine 